cell death; and pinning functional decline to altered DNA is a major challenge.

How can we tell if a theory of ageing is correct? If one underlying process is key to loss of function and death, then slowing it down should also slow down ageing. Vijg points to excitement about one successful application of this approach. The trail-blazing work of Michael Klass, who isolated the first longlived mutant animals in the nematode worm Caenorhabditis elegans, culminated in the discovery of evolutionarily conserved mechanisms for increasing healthy life span. A critical test of a key role for DNA alteration in ageing, would therefore be to reduce it, by increasing the activity of pathways that combat it. For biochemical reasons, this is going to be difficult, however. Vijg gives a fascinating account of single-gene mutations, such as those causing Werner's syndrome, that seem to accelerate some aspects of ageing in humans. Progerias such as Werner's syndrome involve lesions in pathways that sense and repair alterations in DNA, suggesting that these processes are crucial for assuring a normal life span. More telling evidence for a key role for DNA alterations in normal ageing comes from the finding that some types of change in DNA accumulate more slowly in mutant long-lived mice, or when life span is extended by dietary restriction.

If this clear and insightful text has a cloudy patch, it is the account of the evolutionary basis of ageing. Contrary to Vijg's account, a solid mathematical foundation in theoretical population genetics and dynamics has revealed that, despite the loss of fitness it causes, ageing can evolve, through just two routes. Germline mutations with deleterious effects at later ages in adulthood, such as Huntington's disease in humans, can accumulate in populations through mutation pressure. Mutations that cause a benefit earlier in life, such as high fecundity, but at the cost of a higher subsequent rate of ageing, can also enter populations, by natural selection. Vijg points out that detection and repair of DNA alterations is costly, potentially leading to a trade-off between reproduction and somatic maintenance. Mutation pressure could also be important; small, life-long effects on maintenance of the integrity of DNA could lead to variation in the rate of ageing.

This is a work of real scholarship, a critical account of a huge swathe of work with no fewer than 879 references. It will nonetheless be enjoyable for non-specialists, and the opening chapters are a brisk walk through much of modern biology. The sharp focus on one type of damage, the excellent writing style and the well argued, personal perspective of the author contrive to keep the reader going. As Vijg acknowledges, the jury is out on the role of alterations to DNA in ageing, and this text points the way to the kind of research that will be needed to resolve the issue.

Linda Partridge is in the Department of Biology, University College London, Gower Street, London WC1E 6BT, UK.

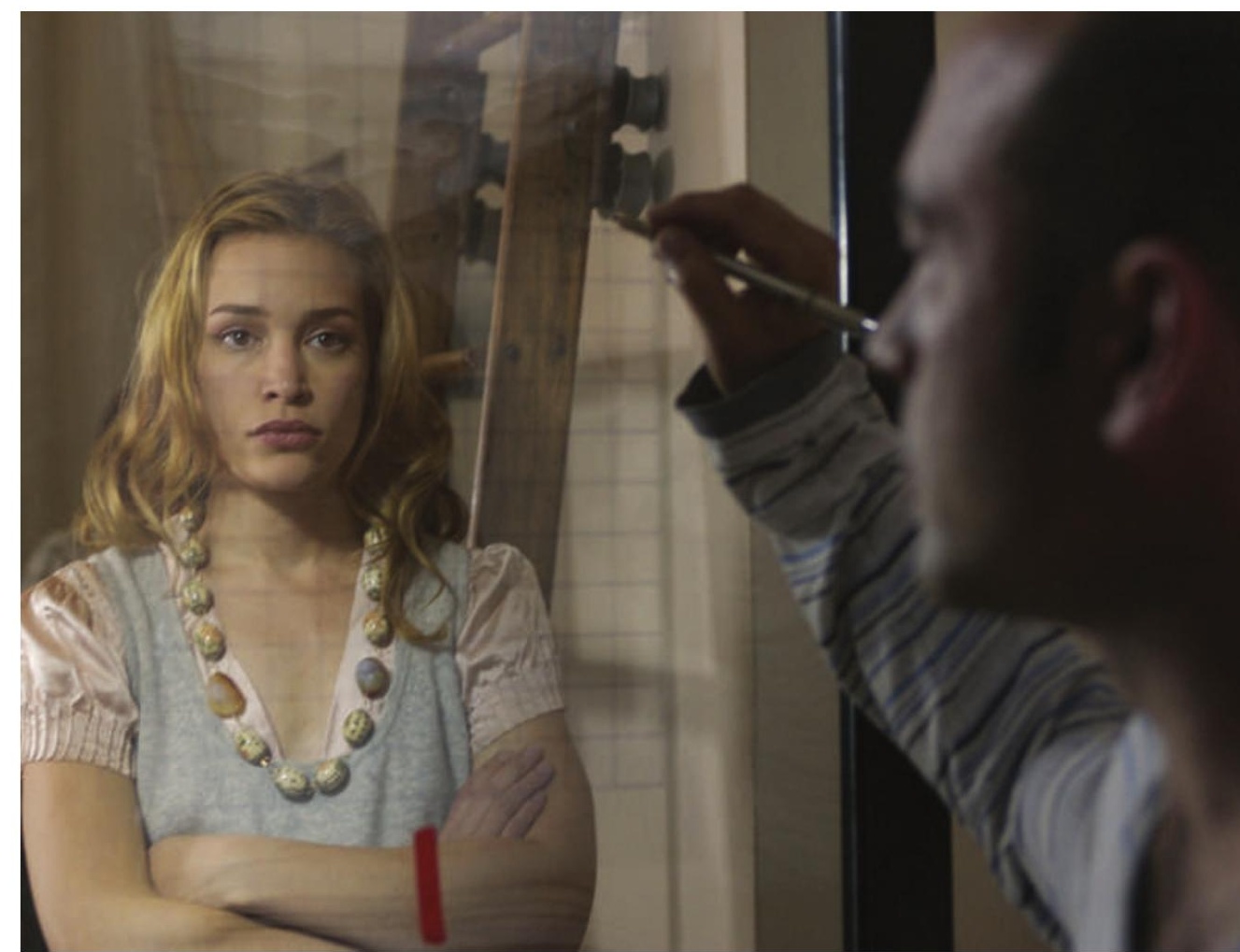

A man with prosopagnosia uses a grid to appreciate his girlfriend's face in the film In Vivid Detail.

FILM

\title{
An unfamiliar face
}

\section{In Vivid Detail \\ directed by Dara Bratt \\ presented by the Alfred P. Sloan Foundation \\ at the Tribeca Film Festival, New York, in spring 2007.}

\section{Emma Marris}

Prosopagnosia is a neurological condition often referred to as 'face blindness'. Individuals with this condition cannot recognize other people by their faces, which look about as uniform to them as two stones do to everyone else. It is a disorder with rich cinematic implications, as film stars often have beautiful or glamorous faces, and films rely on the audience's ability to identify characters by their faces.

In the short film In Vivid Detail, a man falls in love with a conventionally pretty woman, and she reciprocates, only to feel snubbed when he apparently ignores her when she has put her hair up and changed her shoes. He explains his condition, and she must decide whether she can date a man who can't really 'see' her face. In the end, he makes a special effort to show that he can comprehend her face, albeit in a different way to most people.

The man's disorder is revealed in subtle ways before he explains it. Talking about two chocolate-shop owners, he tells his new love "Those guys are brothers," when it is obvious to the viewer that they are identical twins.
And the film almost overdoes it with scenes that reveal his excellent eyesight and attention to detail in other areas.

Student film-maker Dara Bratt spoke with scientists and prosopagnosia patients to do her research, but she admits that she is not sure whether the final conceit, in which the man comes to understand the woman's face by sketching it in a grid and appreciating it as an abstract pattern, would work for people with the condition.

Bratt says she chose a conventional beauty to play the woman so the character would be more startled and upset when the man fails to respond to her pretty face. But this casting choice also puts the audience in the same precarious position of potentially failing to recognize her when she changes her accessories and hairstyle - she could be just another generically pretty blonde. The man's inability to 'see' faces might have been more poignant if the woman's face had more character.

Short films are often used as calling cards in the industry, screened at festivals to introduce a film-maker's work. In Vivid Detail was premiered in this year's Tribeca Film Festival in New York. Bratt says she hopes to do more work on neurological topics, and is already working on feature-length ideas.

http://www.tribecafilmfestival.org

Emma Marris is a reporter for Nature based in Washington DC. 